\title{
Life-cycle assessment for coal-based methanol production in China
}

\author{
Li, Changhang; Bai, Hongtao; Lu, Yuanye; Bian, Jinghong; Dong, Yan; Xu, He
}

Published in:

Journal of Cleaner Production

Link to article, DOI:

10.1016/j.jclepro.2018.04.051

Publication date:

2018

Document Version

Peer reviewed version

Link back to DTU Orbit

Citation (APA):

Li, C., Bai, H., Lu, Y., Bian, J., Dong, Y., \& Xu, H. (2018). Life-cycle assessment for coal-based methanol production in China. Journal of Cleaner Production, 188, 1004-1017.

https://doi.org/10.1016/j.jclepro.2018.04.051

\section{General rights}

Copyright and moral rights for the publications made accessible in the public portal are retained by the authors and/or other copyright owners and it is a condition of accessing publications that users recognise and abide by the legal requirements associated with these rights.

- Users may download and print one copy of any publication from the public portal for the purpose of private study or research.

- You may not further distribute the material or use it for any profit-making activity or commercial gain

- You may freely distribute the URL identifying the publication in the public portal

If you believe that this document breaches copyright please contact us providing details, and we will remove access to the work immediately and investigate your claim. 


\title{
1 Life-cycle assessment for coal-based methanol production in
}

\section{China}

\author{
Changhang $L i^{a}$, Hongtao Bai ${ }^{a, b, *}$, Yuanye Lu ${ }^{a}$, Jinghong Bian ${ }^{c}$, Yan Dong ${ }^{d}$, He Xu ${ }^{a,{ }^{*} *}$ \\ ${ }^{\text {a }}$ College of Environmental Science and Engineering, Nankai University, Tianjin 300350, PR China; \\ ${ }^{b}$ MOE Key Laboratory of Pollution Processes and Environmental Criteria, Nankai University, \\ Tianjin 300350, PR China; \\ ${ }^{\mathrm{c}}$ Beijing Greatwall Enterprise Institute, Beijing 100101, PR China. \\ ${ }^{\mathrm{d}}$ Quantitative Sustainability Assessment, Department of Management Engineering, Technical \\ University of Denmark, Kgs. Lyngby, 2800, Denmark.
}

\begin{abstract}
More methanol is produced and used in China than in any other country. China has a great deal of coal, less oil, and little gas, so the Chinese government is enthusiastically developing the coal-based chemical industry, of which coal-based methanol production is an important part. Coal-based methanol production strongly affects the environment, so the environmental impacts of coal-based methanol production processes must be assessed. Here, two life-cycle assessment models are established using GaBi6 software, and the models and local data for coal-based methanol production are used to establish a life-cycle inventory. The environmental impacts of two typical coal-based methanol production techniques are evaluated using the CML 2001 (mid-point level) method and the Eco-indicator 99 (end-point level) models. The results indicated that less environment harm is caused by producing methanol using the coal coking technology than by producing methanol using the coal gasification technology, especially in terms of acidification, global warming, and photochemical oxidation. In particular, significantly less environmental harm in terms of climate change and radiation is caused by the coal coking technology than by the coal gasification technology. Different sub-processes clearly make different contributions to environmental harm. The results indicated that the methanol production process, heating, and desalination are the main sources of environmental harm for both the coal gasification technology and coal coking technology. Importantly, the public engineering process rather than the methanol production process itself was found to determine emissions for the different methanol production methods.
\end{abstract}

Keywords:

Coal-based methanol production

Coal gasification technology (CGT)

Coal coking technology (CCT)

Life-cycle assessment (LCA)

China

Highlights:

1. A comparative LCA for coal-based methanol production was conducted.

2. The LCI for coal-based methanol based on site-specific investigations was proposed.

3. The impacts of two coal-based methanol production techniques were analyzed.

4. Potential policy implications to lower the related impacts were identified. 
Abbreviations: CGT, Coal gasification technology; CCT, Coal coking technology; COG, Coke Oven Gas; LCA, Life-cycle assessment; LCI, life-cycle inventory; DALY, Disability Adjusted Life Years; PDF, Potentially Disappeared Fraction; ADP, Abiotic depletion potential; AP, Acidification potential; EP, Eutrophication potential; FAETP, Freshwater aquatic eco-toxicity potential; GWP, Global warming potential; ODP, Ozone layer depletion potential; POCP, Photochemical ozone creation potential; TETP, Terrestrial eco-toxicity potential; EQ, Ecosystem quality; AC/NC, Acidification/eutrophication; EC, Eco-toxicity; LC, Land conversion, LU, Land utilization; HH, Human health; CE, Carcinogenic effect; CC, Climate change; OLD, Ozone layer depletion; RA, Radiation; IR, Inhalable inorganic matter; OR, Inhalable organic matter.

\section{Introduction}

After the oil crisis in the 1970s, the nations of the world refocused on the coal-based chemical technology. A few coal-rich countries has carried out research on coal liquefaction and gasification technologies, and South Africa has reached the industrialization stage. China is rich in coal resources but has little natural gas or oil ( Yang et al, 2001; Xie et al, 2010; Li, 2011), making coal the primary source of energy in China. The Chinese government has promoted the development of the coal-based chemical industry to ensure energy security (National Development and Reform Commission, 2017). The coal-based chemical industry in China has developed rapidly, most notably in the production of methanol (Xu et al, 2007; Liu et al, 2008; Xiao, 2010; Liu et al, 2015).

Methanol is an important intermediate product that is commonly used to produce formaldehyde, methyl tert-butyl ether, acetic acid, dimethyl ether, esters, olefins, and other chemicals. Methanol and its derivatives can be used as fuels, pesticides, and medicines and in various industrial processes (Yang et al, 2012). More methanol is produced and consumed in China than in any other country (Shi et al, 2010), and the methanol output capacity of China has increased each year for some time, as shown in Fig. 1 and Table A.1. China produced almost $60 \%$ of all the methanol produced around the world in 2014 (Futures Daily, 2017). The methanol production capacity of China was $10 \times 10^{6} \mathrm{t}$ in 2014 but $30 \times 10^{6} \mathrm{t}$ in 2017 . The dominant driving force of this increase has been many methanol-to-olefin/propylene projects starting production and consistent growth of $10 \%-15 \%$ in the use of methanol as a fuel (Wei, 2014). More than $80 \%$ of the methanol produced in China in 2014 was produced from coal (Xiao, 2015). 


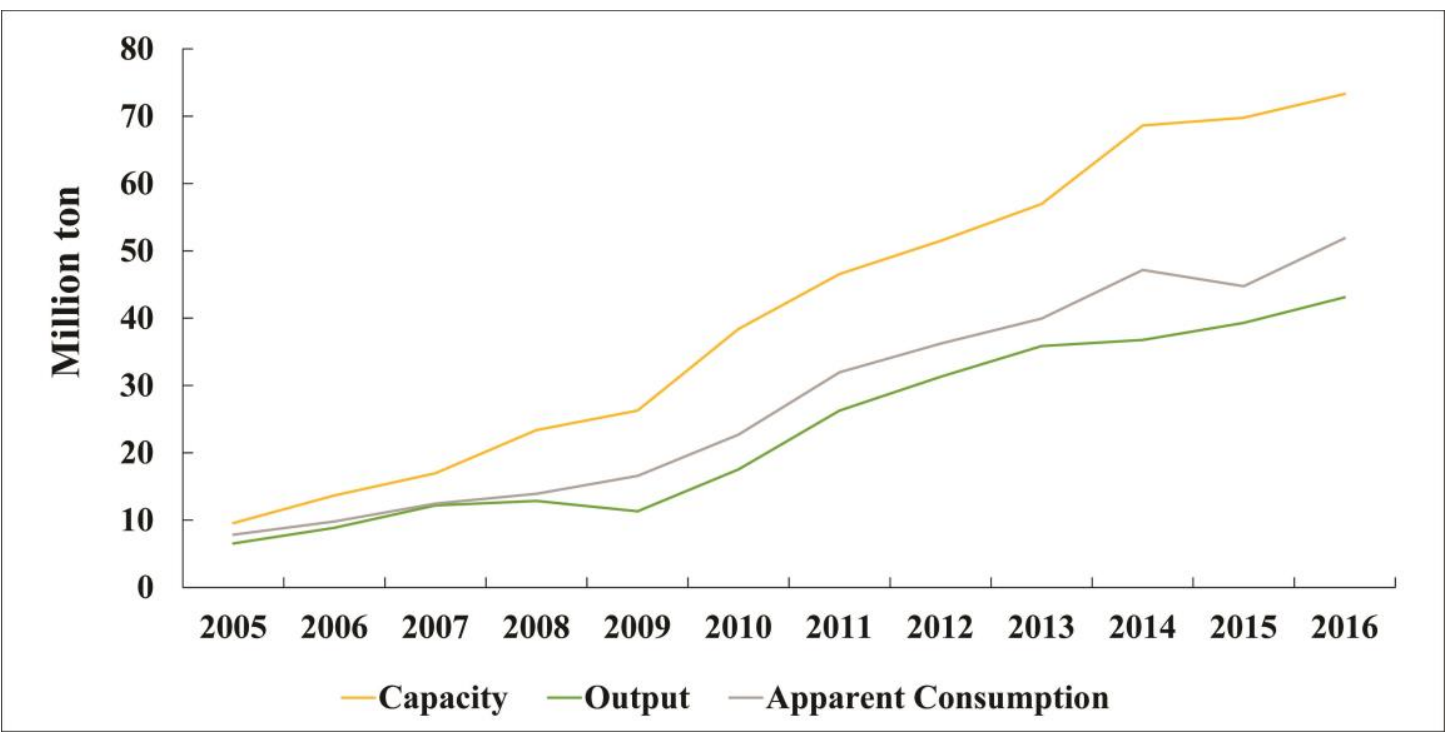

Fig. 1. Production and consumption of methanol in China between 2005 and 2016. Apparent consumption is the sum of annual output and net import. (SCI99.COM, 2017).

Coal-based methanol could provide China with a domestic alternative to imported oil and decrease emissions from conventional fuel used in vehicle engines (Zhang, 2017). However, increased coal-based methanol production could lead to high levels of energy consumption and severe pollution problems that could affect ecosystem and human health (Jackson, 1989, Bhopal et al., 1994; Parodi et al., 2005; Chen, 2008).

There is great controversy about the development of the coal-based methanol industry. Yang and Jackson stated that water resource availability seriously constrains the development of the coal-based methanol production industry in China because coal resources are concentrated in a few provinces that have severely limited water resources (Yang et al, 2012). The production of $1 \mathrm{t}$ of coal-based methanol requires about $20 \mathrm{~m}^{3}$ of fresh water and causes large amounts of wastewater to be produced $(\mathrm{Lu}, 2005$; Chen, 2008). Unsustainable surface water and groundwater extraction and negative impacts on surrounding ecosystems could occur if the coal-based methanol production capacity continues to increase in coal-rich water-limited regions.

Life-cycle assessment (LCA) is a quantitative tool that is widely used to identify the environmental impacts of industrial production. LCA methods have been used to study energy consumption and greenhouse gas emissions when methanol is produced from natural gas or biomass (Borjesson et al, 2011; Brynolf et al, 2014; Deniz et al, 2016). It has been found in several previous studies that coal-based methanol used as a fuel for transportation has a larger carbon dioxide footprint than gasoline, diesel, and methanol produced from natural gas (Zhang, 2005; Zhu, 2006; Wei et al, 2007; Du 2012; Zhang, 2012). Few studies of coal-based methanol production (particularly of different production technologies) have been published because of the range of energy sources used in developed countries (Li et al, 2010; Xia et al, 2015). Local life-cycle 
inventory (LCI) databases for coal-based methanol are fundamental to environmental impact analyses and will facilitate the sustainable development of the Chinese coalbased chemical industry.

A cradle-to-gate LCA for typical coal-based methanol production processes is presented here by use of Gabi6 software. The LCA is based on data for specific coalbased chemical enterprises. The aim was to build a comprehensive LCI for coal-based methanol production in China to allow the environmental impacts of methanol produced using the coal gasification technology (CGT) and coal coking technology (CCT) to be compared. The results are expected to improve the LCI datasets for intermediate industrial products for use in further research and to provide a quantitative basis for stakeholders to improve the decision-making process.

\section{Methods}

\subsection{Coal-based methanol production processes}

The CGT and CCT are currently the main technologies used to produce coal-based methanol (Cao et al, 2006). Here, these two methods are compared using the LCA model. The methods are illustrated schematically in Fig. 2.

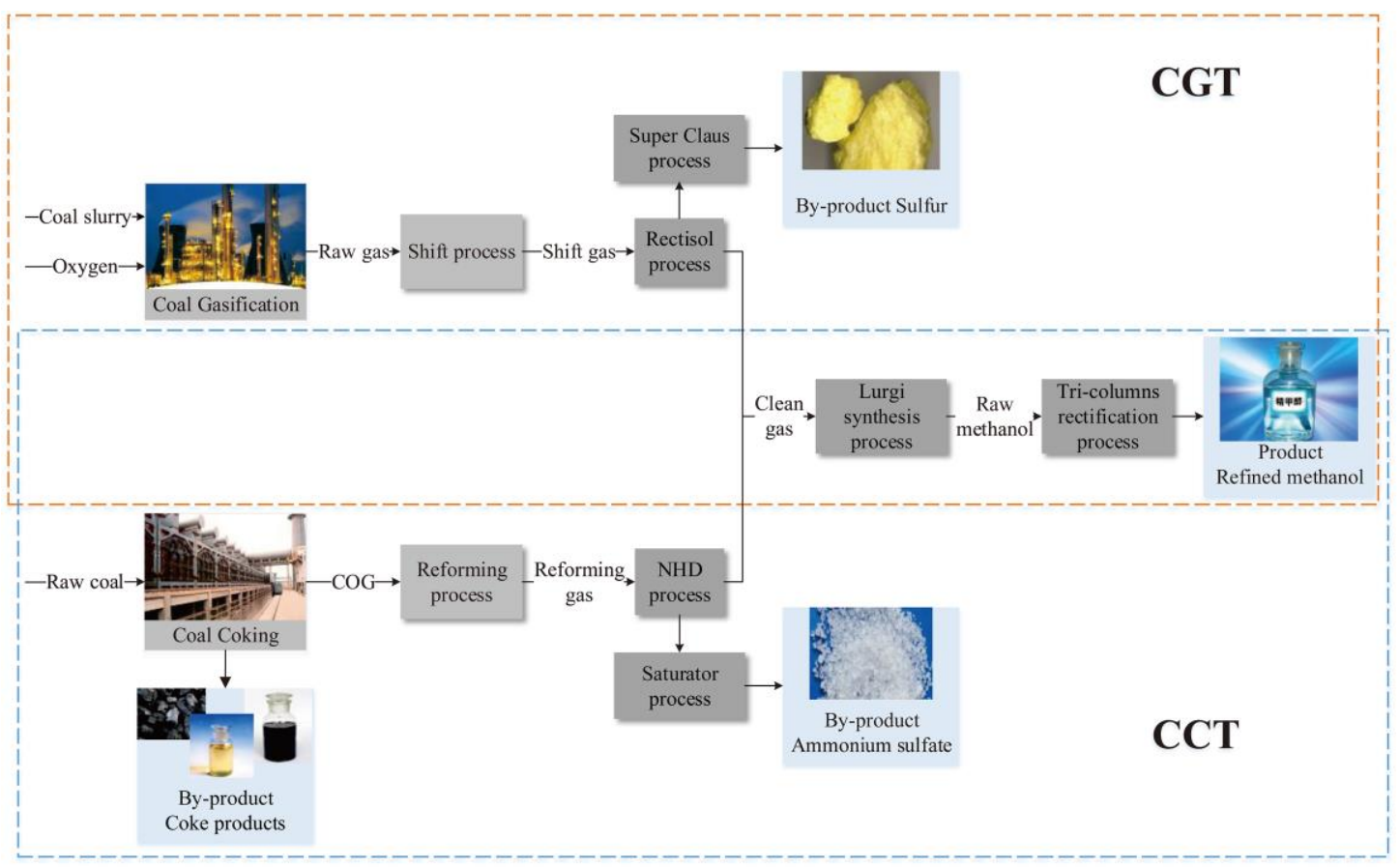

Fig. 2. Schematic diagrams of the coal gasification technology (CGT) and coal coking technology (CCT) used to produce coal-based methanol. COG is the abbreviation of coke oven gas.

Coal-based methanol production processes generally have four steps, syngas generation, syngas purification, methanol synthesis, and methanol rectification. CGT adopted Texaco coal-water slurry gasification technology owing to the mobility and stability of water-coal-slurry. An air separation system supplies oxygen for gasification 
and nitrogen for use in devices in the plant. Coal slurry and oxygen supplied at a high pressure react in a gasifier at a high temperature and pressure, generating raw syngas containing carbon monoxide, hydrogen, carbon dioxide, and other components. The hydrogen concentration is increased using a shift process. The chemical equation for the shift process is shown below.

$$
\mathrm{CO}+\mathrm{H}_{2} \mathrm{O} \rightarrow \mathrm{CO}_{2}+\mathrm{H}_{2} \text {. }
$$

The shift gas is then sent to a purification system in which the carbon dioxide, hydrogen sulfide, and carbon oxysulfide are removed through the Rectisol process and the sulfur recycled through the Super-Claus process. Methanol is then synthesized from a mixture of the clean gas and hydrogen in a Lurgi reactor, in which the reactions shown in Equations 2 and 3 occur. The methanol is then rectified using a three-column rectification process.

$$
\begin{aligned}
& 2 \mathrm{H}_{2}+\mathrm{CO} \rightarrow \mathrm{CH}_{3} \mathrm{OH}, \\
& 3 \mathrm{H}_{2}+\mathrm{CO}_{2} \rightarrow \mathrm{CH}_{3} \mathrm{OH}+\mathrm{H}_{2} \mathrm{O} .
\end{aligned}
$$

The CCT is analogous to the CGT with some small differences. In the CCT, the raw syngas is coke oven gas $(\mathrm{COG})$ produced during the coking process. This syngas contains carbon monoxide, hydrogen, methane, and other chemicals. The coke oven gas is compressed and subjected to incomplete combustion in a reformer (the incomplete combustion reaction is shown in Equation 4). Unlike in the CGT, the purification system uses a polyethylene glycol dimethyl ether technique.

$$
\mathrm{CH}_{4}+\mathrm{H}_{2} \mathrm{O} \rightarrow \mathrm{CO}+3 \mathrm{H}_{2} \text {. }
$$

Equipped with purification system such as desulfurization and dedusting equipment, utilities systems (including heating, desalination, and circulating water systems) provide steam, desalinated water, and circulating water for use throughout the production process. These utilities systems also have impacts on the environment. Waste gas is reused as fuel, but large amounts of gas are emitted or leaked into the atmosphere according to the research data and environmental impact assessment reports, including carbon dioxide, sulfur dioxide, nitrogen oxide and et al. Wastewater is collected through a drainage pipeline and treated using a sequencing batch reactor biochemical treatment system. Waste solids are sent to nearby landfill sites.

\subsection{System boundaries}

The definitions of the system boundaries required by ISO 14040 standards (International Standard Organization, 2006) will determine the LCA results, especially in a comparative study. As shown in Fig. 3, the system boundaries included raw material preparation, transportation, and on-site production, whereas factory buildings and infrastructure was excluded. The use phase and final disposal phase were not considered because methanol is used in a wide range of applications. Methanol was 
treated in this study as an intermediate product, which can supply data for life-cycle studies of downstream products such as dimethyl ether and propylene. To ensure the integrity of the LCI, upstream processes (including hard coal production, natural gas production, and auxiliary material production) were considered, extending to the extraction of natural resources. We only considered the transportation of coal from coal mines to the methanol production plant and the transportation of natural gas through pipelines because of the large amounts used and the long distances the materials are transported. Auxiliary materials are often purchased from different suppliers, so it is hard to define the distances these materials are actually transported. However, auxiliary materials are transported much shorter distances than coal and are much lighter than coal. The first iteration life-cycle impact assessment results indicated that coal transportation contributes $<5 \%$ of the environmental effects of methanol production. We used the cutoff criterion that a flow or a process was excluded from further use if it contributed $<1 \%$ of the cumulative environmental effects (Liu et al, 2016). We assumed that all auxiliary materials were obtained from local suppliers and ignored the transportation of auxiliary materials. No catalysts were considered because catalysts are unchanged during the methanol production process and are only replaced once every few years. As well as the production process, on-site auxiliary engineering processes and public engineering processes were within the boundaries.

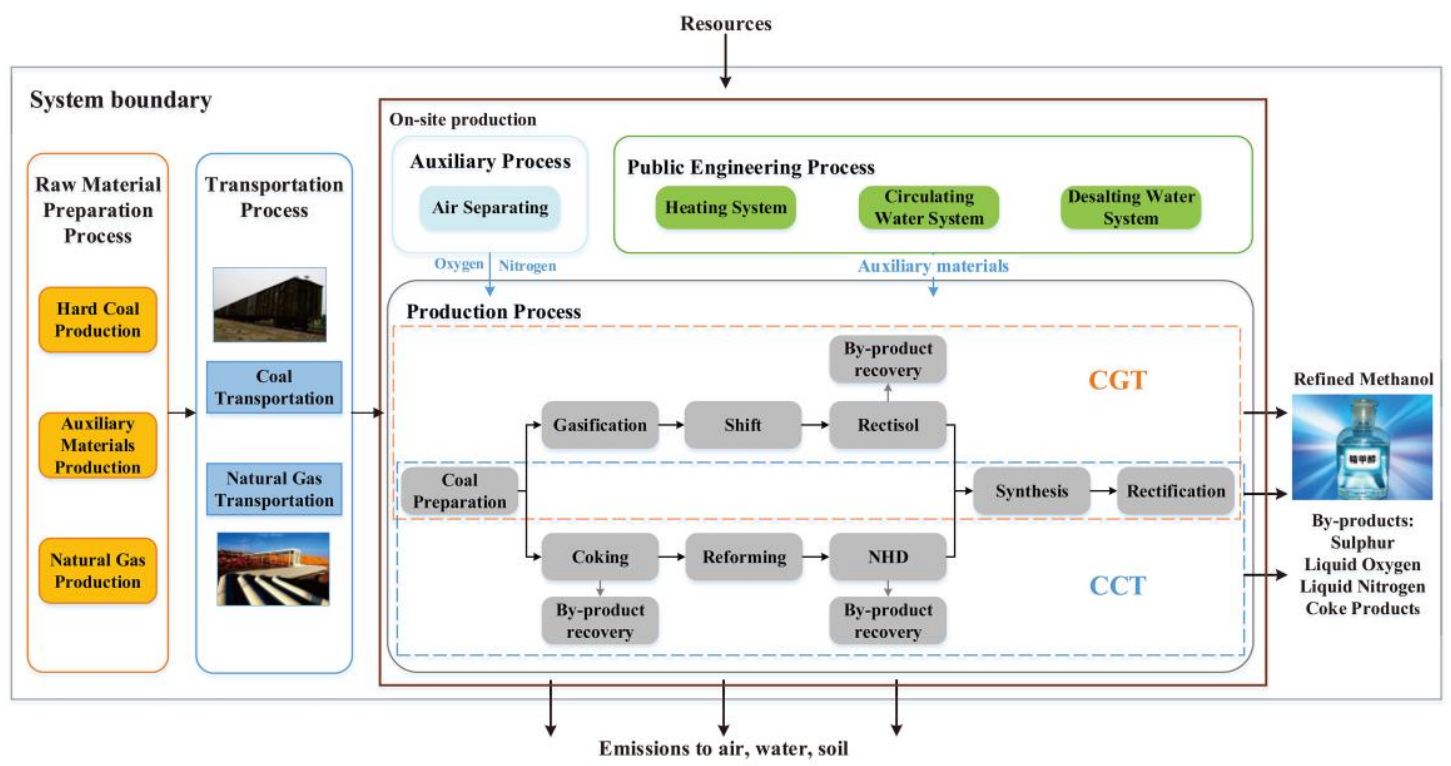

Fig. 3. System boundaries for coal-based methanol production.

\subsection{Functional unit}

The functional unit was defined as $1 \mathrm{t}$ of refined methanol, which is up to the national superior product standard described in the publication "Methanol for industrial use" (General Administration of Quality Supervision, Inspection and Quarantine 
of the P.R. China, 2004) and shown in Table B.2.

\subsection{Data collection}

Data on material and energy consumption, amounts of methanol produced, and pollutant emissions for the on-site production of coal-based methanol were obtained from site-specific investigations and through consulting staff at the CGT plant with annual capacity of 250,000 tons and CCT plant with annual capacity of 300,000 tons. Air pollutant data were determined from on-line monitoring data or through calculating mass balances. We assumed that the regular production processes operated at full capacity under normal working conditions. The materials flows of coal coking technology and coal gasification technology can be found in Fig. A.1 and Fig B.2. Emissions mainly calculated according to the formula below:

$$
\mathrm{E}=\sum_{i=1}^{n} \sum_{j=1}^{m} C_{i j} \times f_{j}
$$

Where $\mathrm{E}$ is the emissions in coal-based methanol production, $\mathrm{C}_{\mathrm{i}}$ is the material or energy consumed in the system $i, f_{j}$ is the emission factors of material or energy $j, n$ is the quantity of the systems in coal-based methanol production, and $\mathrm{m}$ is the quantity of the inputs in coal-based methanol production.

Raw material data: coal was purchased from local coal mines obtaining underground mining technology. Primary data for the raw material preparation processes were obtained from commercial inventory databases, expert estimates, previous publications, and GaBi databases (Weidema and Hischier, 2006; PE International, 2012). For example, hard coal extraction and production, natural gas production, and chemical production data were obtained from $\mathrm{GaBi}$ databases.

Energy data: steam used in a methanol production process is mainly supplied by the heating system at the plant. Data for material consumption and emissions were provided by the plant staff. Electricity consumption data were not available, so we assumed that all electricity was supplied by the local power grid. The LCI dataset for electricity in the latest GaBi database for the Chinese electricity grid (2009) was used. This database takes the efficiencies of different techniques and energy carriers into account (Liu et al, 2016).

Transportation data: the distances hard coal and natural gas are transported to the plants was obtained through on-site investigations. Basic LCI data for rail transport of a $100 \mathrm{t}$ payload and for transporting gas $100 \mathrm{~km}$ through a pipeline were obtained from the transportation models in the GaBi databases.

\subsection{Allocations}

The CGT and CCT both give by-products that some of the energy inputs and environmental emissions should be allocated to. Three different approaches (mass basis, 
volume basis, and energy basis) are usually used to allocate energy and emissions for a multi-product system. The different states of the different products meant that it was appropriate to allocate energy inputs and environmental burdens during methanol production on an energy basis (Soam et al, 2015). Net calorific values were used to perform energy calculations. The net calorific value was multiplied by the mass of a product to give the energy content of the product. The allocation factor was defined as the contribution of each product to the total energy content. The allocation factors for the products are shown in Table 1.

\section{Table 1}

229 Allocation factors for the products of coal-based methanol production.

\begin{tabular}{|c|c|c|c|c|c|c|c|}
\hline \multirow[t]{2}{*}{ Product } & \multirow{2}{*}{$\begin{array}{l}\text { Average net } \\
\text { calorific value } \\
(\mathrm{kJ} / \mathrm{kg})^{\mathrm{a}}\end{array}$} & \multicolumn{3}{|l|}{ CGT } & \multicolumn{3}{|l|}{$\mathrm{CCT}$} \\
\hline & & $\operatorname{Mass}(\mathrm{kg})$ & $\begin{array}{l}\text { Energy } \\
\text { content } \\
(\mathrm{MJ})\end{array}$ & $\begin{array}{l}\text { Allocation } \\
\text { factor }\end{array}$ & Mass (kg) & $\begin{array}{l}\text { Energy } \\
\text { content } \\
(\mathrm{MJ}) \\
\end{array}$ & $\begin{array}{l}\text { Allocation } \\
\text { factor }\end{array}$ \\
\hline Methanol & 20090 & 1000 & 20090 & $80.92 \%$ & & & \\
\hline Metallurgical coke & 28435 & & & & 17053 & 484902.06 & $79.67 \%$ \\
\hline Coke oven gas & 44952 & & & & 1868 & 83970.34 & $13.80 \%$ \\
\hline Tar & 33453 & & & & 870 & 29104.11 & $4.78 \%$ \\
\hline Crude benzene & 41816 & & & & 244 & 10203.10 & $1.68 \%$ \\
\hline Sulfur & 9260 & 6.37 & 58.99 & $0.24 \%$ & 51 & 472.26 & $0.08 \%$ \\
\hline Steam & 3763 & 1243 & 4677.41 & $18.84 \%$ & & & \\
\hline
\end{tabular}

230 a Source: General Administration of Quality Supervision, Inspection and Quarantine of the P.R.

231 China (2008), Grote and Antonsson (2009), Wu et al, (2016).

2.6 LCI and life-cycle impact assessment methods

233 The objective was to evaluate and compare the environmental impacts of the two 234 coal-based methanol production methods at the mid-point (MP) and end-point (EP) 235 levels. The MP level assessment is problem-oriented, environmental problem targeted, 236 and simulates the environmental mechanisms between the pollutant being emitted and 237 causing damage but neglects the effects of environmental damage on resources, 238 ecosystems, and humans (Dreyer et al, 2003). The EP level assessment is a damage239 oriented method that simulates the negative impacts on human and ecosystem health 240 and on resources.

241 The CML 2001 method was used to assess MP level environmental impacts 242 (Centre for Environmental Studies, 2001). The characteristics of the coal-based 243 chemical industry and the attention it receives led us to choose eight typical impact 244 categories in the CML 2001 method as indicators at the MP level (Guinee et al, 2001). 245 These impact categories, shown in Table 2, were focused on the environmental 
problems caused by coal-based methanol production.

For the EP level assessment, 10 impact categories, shown in Table 2, were identified using the Eco-indicator 99 (EI99) method for evaluating the impacts on ecosystem and human health (Luan, 2004; Goran et al, 2009). Unlike the CML2001 method, the EI99 method includes three damage categories, human health, ecosystem quality, and resources. The EI99 method is used to evaluate the EP environmental impacts on human health and ecosystems caused by dust and toxic substance emissions from coal-based chemical plants (Goedkoop et al, 1999). We used human health and ecosystem quality to assess the damage caused by coal-based methanol production. Human health was expressed as disability adjusted life years (DALY) that is the sum of years of life lost and years of life disabled, and ecosystem quality was expressed as a potentially disappeared fraction (PDF) that is a fraction of species richness that may be potentially lost due to an environmental mechanism.

The EI99 method contains three methods, based on culture theory, for reflecting stakeholders attitudes to the environment. These methods are the egalitarian perspective, the hierarchical perspective, and the individualist perspective. We used the hierarchical perspective, which is widely used and the closest to the actual situation (Hofsterter, 2000; Huisman, 2003).

Table 2

Impact categories for the CML2001 and Eco-indicator 99 (EI99) models.

\begin{tabular}{lll}
\hline Method & Problem/Damage & Category \\
\hline CML2001 & Depletion of abiotic resources & Abiotic depletion potential \\
& (ADP) \\
& Acidification & Acidification potential (AP) \\
& Eutrophication & Eutrophication potential (EP) \\
Eco-toxicity & Freshwater aquatic eco- \\
& & toxicity potential (FAETP) \\
& & Terrestrial eco-toxicity \\
& Climate change & potential (TETP) \\
& Global warming potential \\
Stratospheric ozone depletion & (GWP) \\
& Ozone layer depletion \\
Photo-oxidant formation & potential (ODP) \\
& Photochemical ozone creation \\
& Ecosystem quality (EQ) & potential (POCP) \\
Damage caused by the combined effect of & Acidification/eutrophication \\
acidification and eutrophication & (AC/NC) \\
Damage caused by eco-toxic & Eco-toxicity (EC) \\
Damage caused by land conversion & Land conversion (LC) \\
\hline
\end{tabular}




\begin{tabular}{lll}
\hline Method & Problem/Damage & Category \\
\hline Damage caused by land utilization & Land utilization (LU) \\
Human health $(\mathrm{HH})$ & \\
Carcinogenic effects on humans & Carcinogenic effect (CE) \\
Damage caused by climate change & Climate change (CC) \\
Effects caused by ozone layer depletion & Ozone layer depletion (OLD) \\
Effects caused by lonising radiation & Radiation (RA) \\
Respiratory effects caused by inorganic & Inhalable inorganic matter \\
substances & (IR) \\
Respiratory effects caused by organic & Inhalable organic matter (OR) \\
substances &
\end{tabular}

\section{Results and discussion}

\subsection{LCI results}

The complete inventory, from cradle to gate, for coal-based methanol production using the CGT and CCT is shown in Table 3. The inventory includes the methanol production process, auxiliary engineering processes, public engineering processes, and upstream and downstream processes, but excludes the consumption of resources or pollutant emissions contributing $<1 \%$ of the total input and output mass. As shown in

273 the LCI, the material types for the CGT and CCT were essentially the same. There were

27413 types of input materials directly extracted from the environment (including 275 nonrenewable energy and resources and renewable resources). There were four types 276 of output materials, stock, discharges to the air, discharges to water, and discharges to 277 soil. Stock includes waste, gangue, degraded products, and surface soil (accumulation).

278 Material discharged to the air was dominated by 13 heavy metals, 19 inorganic 279 chemicals, and 18 organic chemicals. Material discharged to water was dominated by 28014 heavy metals, 31 inorganic chemicals, five organic chemicals, and radioactive matter 281 (Ra). Agricultural and industrial soils are affected by emissions. Material discharged to 282 agricultural soil was dominated by three heavy metals and four inorganic chemicals. 283 Material discharged to industrial soil was dominated by one heavy metal and six 284 inorganic chemicals.

\section{Table 3}

286 Life-cycle inventory for the production of $1 \mathrm{t}$ of coal-based methanol.

\begin{tabular}{lcclcc}
\hline Subcategory/Unit & CGT & CCT & Subcategory/Unit & CGT & CCT \\
\hline Unrenewable energy & & & & & \\
$\quad$ Crude oil/kg & 20.21 & 5.54 & Lignite/t & 8.41 & 2.28 \\
$\quad$ Hard coal/t & 0.50 & 0.20 & Natural gas $/ \mathrm{kg}$ & 73.38 & 10.22 \\
$\quad$ Unrenewable resource & & & & & \\
$\quad$ Inert rock/t & 3.64 & 0.72 & Limestone $/ \mathrm{kg}$ & 232.24 & 28.05 \\
Renewable resource & & & & & \\
\hline
\end{tabular}




\begin{tabular}{|c|c|c|c|c|c|}
\hline Fresh water/t & 64.81 & 13.15 & River water/t & 2184.23 & 276.42 \\
\hline Underground water/t & 2.94 & 0.77 & Sea water/t & 10.89 & 1.34 \\
\hline Lake water/t & 135.52 & 18.15 & Air/t & 14.75 & 5.45 \\
\hline Rain/t & 2.64 & 0.44 & & & \\
\hline \multicolumn{6}{|l|}{ Waste(stock) } \\
\hline Highly radioactive waste/g & 2.75 & 0.34 & Surface soil (accumulation)/kg & 3671.90 & 721.09 \\
\hline Low radioactive waste/g & 33.97 & 4.16 & Degraded product $/ \mathrm{kg}$ & 15.25 & 3.53 \\
\hline Moderately radioactive waste/g & 16.15 & 1.98 & Gangue/kg & 2.60 & 0.29 \\
\hline Radioactive gangue $/ \mathrm{kg}$ & 1.76 & 0.22 & Waste $/ \mathrm{kg}$ & 9.61 & 2.37 \\
\hline Hazardous waste/g & 7.79 & 1.56 & & & \\
\hline \multicolumn{6}{|l|}{ Heavy metal to air ${ }^{\mathrm{a}}$} \\
\hline $\mathrm{Sb} / \mathrm{g}$ & 1.02 & 0.47 & $\mathrm{Mn} / \mathrm{g}$ & 2.64 & 1.17 \\
\hline $\mathrm{As} / \mathrm{g}$ & 0.55 & 0.24 & $\mathrm{Ni} / \mathrm{g}$ & 2.98 & 1.38 \\
\hline $\mathrm{Cr} / \mathrm{g}$ & 1.83 & 0.84 & $\mathrm{Se} / \mathrm{g}$ & 0.55 & 0.22 \\
\hline $\mathrm{Co} / \mathrm{g}$ & 0.60 & 0.28 & $\mathrm{Sn} / \mathrm{g}$ & 1.57 & 0.71 \\
\hline $\mathrm{Cu} / \mathrm{g}$ & 0.92 & 0.42 & $\mathrm{~V} / \mathrm{g}$ & 3.12 & 1.40 \\
\hline $\mathrm{Pb} / \mathrm{g}$ & 4.09 & 1.89 & $\mathrm{Zn} / \mathrm{g}$ & 5.26 & 2.38 \\
\hline \multicolumn{6}{|l|}{ Inorganic matter to air ${ }^{\mathrm{a}}$} \\
\hline Ammonia $\left(\mathrm{NH}_{3}\right) / \mathrm{kg}$ & 0.02 & 0.04 & Hydrogen fluoride (HF)/g & 3.87 & 1.16 \\
\hline $\mathrm{Ba} / \mathrm{g}$ & 12.28 & 5.59 & Hydrogen sulphide $\left(\mathrm{H}_{2} \mathrm{~S}\right) / \mathrm{g}$ & 40.78 & 10.77 \\
\hline Boron compound/g & 3.90 & 1.34 & Nitrogen $\left(\mathrm{N}_{2}\right) / \mathrm{t}$ & 3.45 & 1.44 \\
\hline Bromine $(\mathrm{Br}) / \mathrm{g}$ & 1.85 & 0.75 & Nitrogen oxide $\left(\mathrm{NO}_{\mathrm{x}}\right) / \mathrm{kg}$ & 32.17 & 5.21 \\
\hline Carbon dioxide $\left(\mathrm{CO}_{2}\right) / \mathrm{t}$ & 17.53 & 2.84 & Oxygen $\left(\mathrm{O}_{2}\right) / \mathrm{kg}$ & 17.54 & 2.14 \\
\hline Carbon monoxide $(\mathrm{CO}) / \mathrm{kg}$ & 1.66 & 0.91 & Ozone $\left(\mathrm{O}_{3}\right) / \mathrm{g}$ & 0.11 & 0.04 \\
\hline Chlorine $(\mathrm{Cl}) / \mathrm{g}$ & 0.42 & 0.12 & Sulfate/g & 0.44 & 0.13 \\
\hline Fluoride/g & 0.30 & 0.04 & Sulphur dioxide $\left(\mathrm{SO}_{2}\right) / \mathrm{kg}$ & 47.86 & 5.91 \\
\hline Hydrogen $\left(\mathrm{H}_{2}\right) / \mathrm{g}$ & 32.40 & 3.51 & Steam $/ \mathrm{t}$ & 10.54 & 4.21 \\
\hline Chlorine hydride $(\mathrm{HCl}) / \mathrm{g}$ & 45.42 & 6.92 & & & \\
\hline \multicolumn{6}{|l|}{ Organic matter to air ${ }^{\mathrm{a}}$} \\
\hline NMVOC $/ \mathrm{kg}$ & 0.56 & 0.16 & Methane $/ \mathrm{kg}$ & 4.36 & 1.63 \\
\hline $\mathrm{VOC} / \mathrm{g}$ & 1.33 & 0.11 & & & \\
\hline \multicolumn{6}{|l|}{ Other emissions to air ${ }^{\mathrm{a}}$} \\
\hline Other emission/t & 55.70 & 3.10 & & & \\
\hline \multicolumn{6}{|l|}{ Heavy metal to water ${ }^{\mathrm{b}}$} \\
\hline As $(+V) / g$ & 15.89 & 6.43 & Iron ion/g & 2.43 & 0.72 \\
\hline $\mathrm{Cd}(+\mathrm{II}) / \mathrm{g}$ & 57.52 & 23.33 & $\mathrm{~Pb}(+\mathrm{II}) / \mathrm{g}$ & 5.30 & 2.10 \\
\hline $\mathrm{Cr}(+\mathrm{III}) / \mathrm{g}$ & 6.41 & 2.59 & $\mathrm{Mn}(+\mathrm{II}) / \mathrm{g}$ & 16.82 & 6.68 \\
\hline $\mathrm{Cr}(+\mathrm{VI}) / \mathrm{g}$ & 6.40 & 2.59 & $\mathrm{Hg}(+\mathrm{II}) / \mathrm{g}$ & 8.95 & 3.63 \\
\hline $\mathrm{Co} / \mathrm{g}$ & 15.76 & 6.39 & $\mathrm{Ni}(+\mathrm{II}) / \mathrm{g}$ & 16.09 & 6.51 \\
\hline $\mathrm{Cu}(+\mathrm{II}) / \mathrm{g}$ & 5.19 & 2.09 & $\mathrm{Tl} / \mathrm{g}$ & 15.76 & 6.39 \\
\hline $\mathrm{Fe} / \mathrm{kg}$ & 0.34 & 0.04 & $\mathrm{Zn}(+\mathrm{II}) / \mathrm{g}$ & 9.16 & 3.69 \\
\hline \multicolumn{6}{|l|}{ Inorganic matter to water ${ }^{\mathrm{b}}$} \\
\hline $\mathrm{Al}(+\mathrm{III}) / \mathrm{g}$ & 10.37 & 2.50 & Neutral salt/g & 74.21 & 6.26 \\
\hline Ammonia $\left(\mathrm{NH}_{3}\right) / \mathrm{g}$ & 23.07 & 8.61 & Nitrate $/ \mathrm{kg}$ & 0.80 & 0.31 \\
\hline
\end{tabular}




\begin{tabular}{|c|c|c|c|c|c|}
\hline Ammonium/g & 12.42 & 1.39 & Nitrogen/kg & 0.68 & 0.28 \\
\hline $\mathrm{Ba} / \mathrm{g}$ & 4.51 & 0.56 & Phosphate/kg & 0.08 & 0.03 \\
\hline Boron/g & 4.11 & 1.48 & Phosphorus/kg & 0.08 & 0.03 \\
\hline Bromate/g & 1.60 & 0.50 & Kalium/g & 5.07 & 0.85 \\
\hline Brmine/g & 3.07 & 0.34 & Potassium-ion/g & 0.60 & 4.99 \\
\hline Carbonate/g & 27.79 & 7.36 & $\mathrm{Na}(+\mathrm{I}) / \mathrm{kg}$ & 0.69 & 0.14 \\
\hline Chlorate/g & 12.24 & 3.82 & $\mathrm{Na}_{2} \mathrm{SO}_{4} / \mathrm{g}$ & 12.48 & 1.54 \\
\hline Chloride/kg & 9.45 & 3.05 & Sodion $/ \mathrm{kg}$ & 0.09 & 0.09 \\
\hline $\mathrm{Cl}$ (dissolved)/g & 8.22 & 1.00 & Strontium/g & 3.49 & 1.17 \\
\hline Fluoride/kg & 1.79 & 0.65 & Sulfate $/ \mathrm{kg}$ & 2.46 & 0.69 \\
\hline Lithium/g & 7.70 & 0.65 & Sulfide/g & 4.48 & 1.25 \\
\hline Lithium-ion/g & 7.31 & 0.98 & Sulfite/g & 1.22 & 0.44 \\
\hline Magnesium/kg & 0.15 & 0.05 & Sulphur/g & 0.05 & 1.65 \\
\hline Magnesium-ion/g & 4.55 & 0.38 & & & \\
\hline \multicolumn{6}{|c|}{ Organic matter to water ${ }^{\mathrm{b}}$} \\
\hline Hydrocarbon/g & 17.41 & 2.47 & Propylene/g & 8.46 & 0.70 \\
\hline Methyl alcohol/g & 1.82 & 0.19 & Suspended solids/g & 0.71 & 0.16 \\
\hline Petroleum/g & 5.71 & 1.42 & & & \\
\hline \multicolumn{6}{|c|}{ Radioactive matter to water ${ }^{\mathrm{b}}$} \\
\hline Radium(Ra226)/t & 136.30 & 16.84 & & & \\
\hline \multicolumn{6}{|l|}{ Other emission } \\
\hline Water/g & 91.54 & 29.64 & Rainwater/kg & 0.08 & 0.01 \\
\hline Clear water/g & 3.87 & 1.44 & Turbine drainage/t & 2253.54 & 279.29 \\
\hline Cooling water/g & 58.92 & 13.56 & Process waste water/t & 6.87 & 2.44 \\
\hline \multicolumn{6}{|c|}{ Heavy metal to agricultural soil ${ }^{\mathrm{c}}$} \\
\hline $\mathrm{Fe} / \mathrm{mg}$ & 256.09 & 93.80 & $\mathrm{Zn}(+\mathrm{II}) / \mathrm{mg}$ & 143.73 & 32.05 \\
\hline $\mathrm{Pb}(+\mathrm{II}) / \mathrm{mg}$ & 55.33 & 12.33 & & & \\
\hline \multicolumn{6}{|c|}{ Inorganic matter to agricultural soil $^{c}$} \\
\hline $\mathrm{Al} / \mathrm{mg}$ & 37.51 & 13.99 & $\mathrm{Si} / \mathrm{mg}$ & 91.57 & 30.02 \\
\hline $\mathrm{Ca} / \mathrm{mg}$ & 225.09 & 76.10 & $\mathrm{~S} / \mathrm{mg}$ & 32.93 & 12.14 \\
\hline \multicolumn{6}{|c|}{ Heavy metal to industrial soil ${ }^{\mathrm{c}}$} \\
\hline $\mathrm{Fe} / \mathrm{g}$ & 0.52 & 0.15 & & & \\
\hline \multicolumn{6}{|c|}{ Inorganic matter to industrial soil ${ }^{\mathrm{c}}$} \\
\hline $\mathrm{Al} / \mathrm{mg}$ & 67.95 & 15.53 & $\mathrm{Cl} / \mathrm{mg}$ & 32.07 & 51.24 \\
\hline $\mathrm{Ca} / \mathrm{mg}$ & 268.25 & 56.72 & $\mathrm{Mg} / \mathrm{mg}$ & 54.61 & 11.44 \\
\hline Chloride/g & 5.75 & 0.73 & $\mathrm{Na} / \mathrm{mg}$ & 147.46 & 32.62 \\
\hline
\end{tabular}

287 a Source: $\mathrm{CO}_{2}$ and $\mathrm{CH}_{4}$ emissions are derived from the Ecoinvent Database v2.2 (Weidema and

288 Hischier, 2006). The emissions to air of heavy metals, other inorganic matters and organic matters

289 come from the companies that represent the current domain coal-based methanol production in

290 China.

$291{ }^{\mathrm{b}}$ Source: COD, ammonia, sulphide, oil and SS are based on the Emission Factor Manual for the $1^{\text {st }}$

292 National Census of Industrial Pollution Sources (The State Council of China). 


\subsection{MP level analysis}

\subsubsection{Comparative total impact analysis}

The life-cycle impact assessment results at the MP level for the CGT and CCT are shown in Table 4. The environmental impacts in all impact categories were much greater for the CGT than for the CCT, especially for the acidification potential (AP), global warming potential (GWP), and photochemical ozone creation potential (POCP). The CGT to CCT method ratios for AP, GWP, and POCP were 6.7, 6.1, and 5.6, respectively. The smallest environmental burden gap between the two methods was for the terrestrial eco-toxicity potential (TETP), the CGT to CCT method ratio for which was 2.5. The main reason for the difference in impacts was that the coke oven gas is only one of numerous products of the coke production system. We distributed the environmental impacts of the upstream processes among the products and by-products on an energy basis. For the coking process, the energy content of coke oven gas accounted for $13.8 \%$ of the total energy content. Using $1 \mathrm{t}$ of coal-based methanol as the functional unit, we determined that methanol production contributed $13.8 \%$ of total impacts of the coking process, making the environmental performance better for the CCT than for the CGT.

Table 4

Integral environmental impact assessment result at the mid-point level.

\begin{tabular}{lllll}
\hline Categories & Unit & CGT & CCT & CGT/CCT \\
\hline ADP & MJ & $8.68 \mathrm{E}+04$ & $2.45 \mathrm{E}+04$ & 3.5 \\
AP & kg SO -eq & $7.37 \mathrm{E}+01$ & $1.10 \mathrm{E}+01$ & 6.7 \\
EP & kg Phosphate-eq & $4.98 \mathrm{E}+00$ & $1.33 \mathrm{E}+00$ & 3.7 \\
FAETP & kg DCB-eq & $3.65 \mathrm{E}+02$ & $1.47 \mathrm{E}+02$ & 2.5 \\
GWP & kg CO -eq & $1.77 \mathrm{E}+04$ & $2.89 \mathrm{E}+03$ & 6.1 \\
ODP & kg R11-eq & $1.37 \mathrm{E}-05$ & $4.15 \mathrm{E}-06$ & 3.3 \\
POCP & kg Ethene-eq & $3.53 \mathrm{E}+00$ & $6.33 \mathrm{E}-01$ & 5.6 \\
TETP & kg DCB-eq & $1.89 \mathrm{E}+01$ & $7.98 \mathrm{E}+00$ & 2.4 \\
\hline
\end{tabular}

3.2.2. Comparative process impact analysis

We used eight environmental impact categories for the CCT and CGT for five processes (raw material preparation, transportation, auxiliary engineering processes, public engineering processes, and methanol production). The relative contributions of the processes to each impact category for the two methods are shown in Fig. 4. 

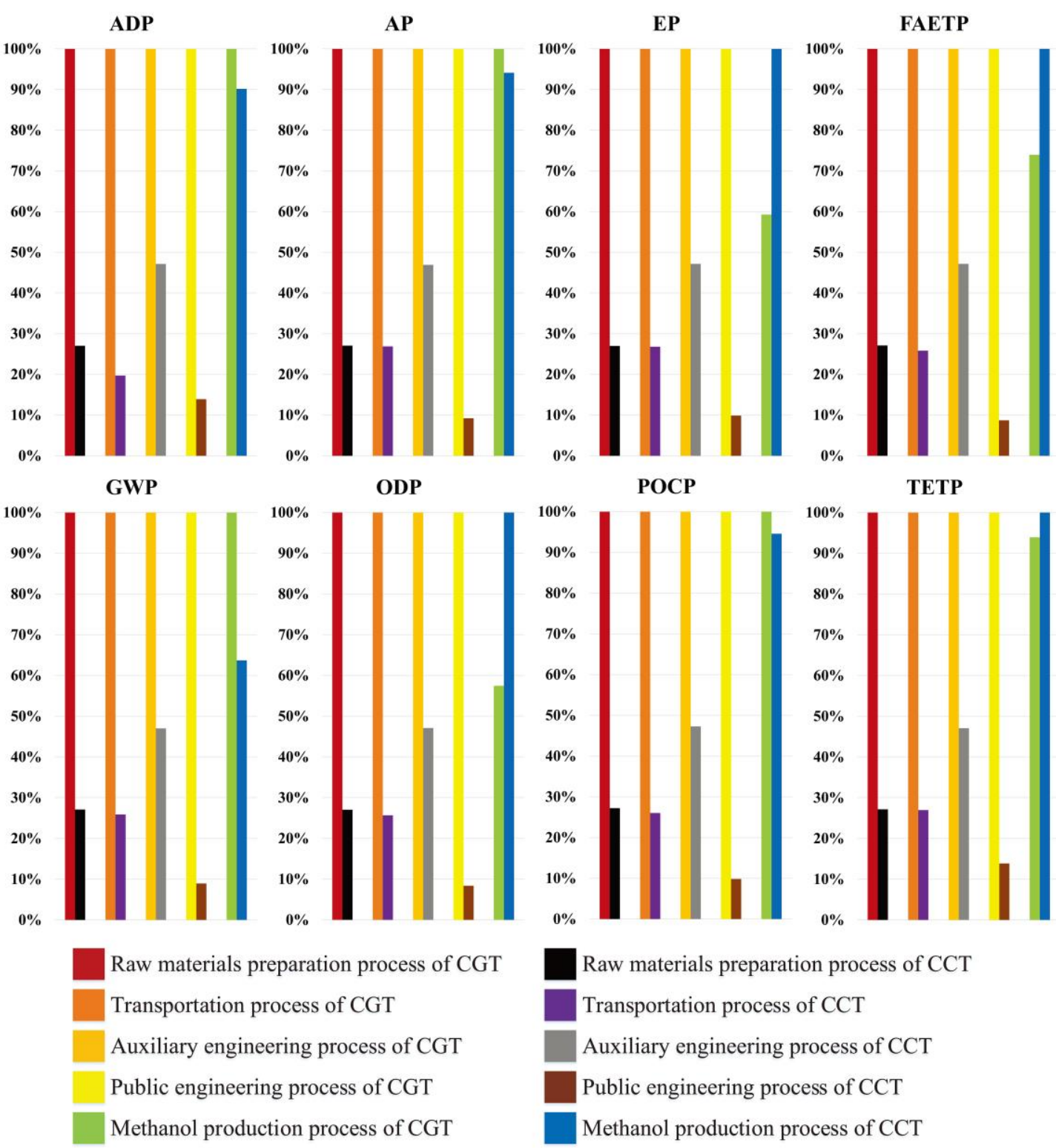

POCP

TETP
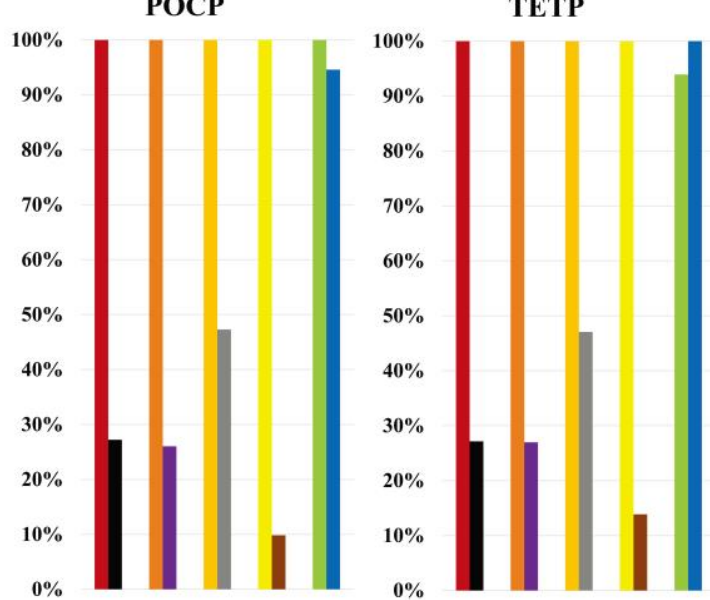

Fig. 4. Environmental impact assessment for specific processes at the mid-point level.

For raw material preparation, the CGT impacts were about $73 \%$ higher than the CCT impacts because more energy and resources are consumed by the CGT. For methanol production, the abiotic depletion potential (ADP), AP, GWP, and POCP impacts were lower for the CCT than for the CGT, but not by $>10 \%$ except for GWP, which was 36\% lower. The eutrophication potential (EP), freshwater aquatic ecotoxicity potential (FAETP), and ozone layer depletion potential (ODP) impacts were $25 \%-42 \%$ higher for the CCT than for the CGT. TETP emissions were only $6 \%$ higher for the CCT than for the CGT. Unlike for the other four processes, there were no clear differences in the impacts of methanol production process using the two methods. Auxiliary engineering processes had 53\% higher impacts in all categories for the CGT than for the CCT because coal gasification consumes large amounts of oxygen (to react with the coal-water slurry) whereas the CCT uses a product of coking to produce 
methanol and does not require large amounts of additional oxygen. Transportation had approximately $73 \%$ lower impacts in all categories for the CCT than for the CGT because less coal is used in the CCT than in the CGT and no natural gas is used in the CCT. Public engineering processes had $90 \%$ lower impacts in all categories for the CCT than for the CGT. The public engineering processes for both methods and environmental impacts per product unit were the same, so the difference was mainly caused by steam, desalinated water, and circulating water, each of which are used in smaller quantities in the CCT than in the CGT.

\subsubsection{Comparative sub-process impact analysis}

The pollution sources were explored further by splitting the CGT and CCT into eight sub-processes, as shown in Fig. 5.
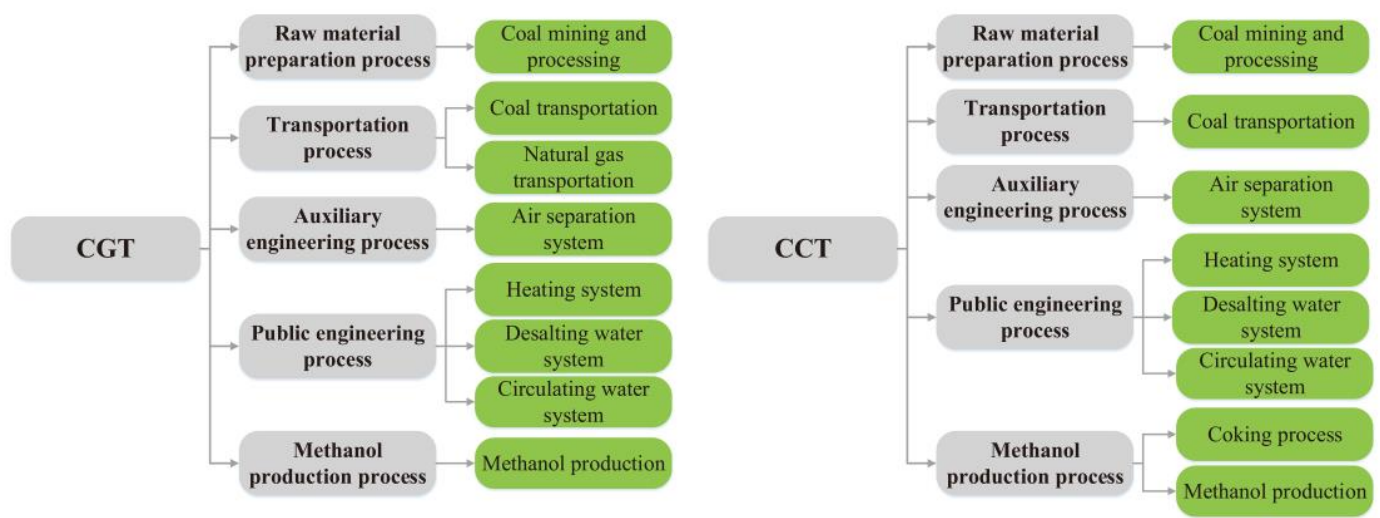

Fig. 5. Sub-processes in the coal gasification technology (CGT) and coal coking technology (CCT).

The contributions of the sub-processes to the environmental impact categories for the CGT are shown in Fig. 6. Methanol production, heating, and desalination were found to be the main contributors to the environmental burden. Methanol production contributed $5.26 \%-30.32 \%$ of the impact categories, contributing least to ADP and most to TETP. Heating contributed $3.54 \%-84.90 \%$ of the impact categories ( $>60 \%$ to AP, EP, GWP, and POCP). Desalination contributed $5.39 \%-73.64 \%$ of the impact categories, and strongly contributed to FAETP, ODP, and TETP. In addition to transportation itself, natural gas transportation included gas exploitation and processing. Natural gas is mainly transported by pipeline, meaning only electricity is consumed, and gas exploitation and processing have lower environmental impacts than do coal mining and processing. Natural gas is a "clean energy" that maintain the operation of steam superhearter in the CGT, so its demands are rather small, so the contributions of natural gas transportation to the impact categories were very small. 


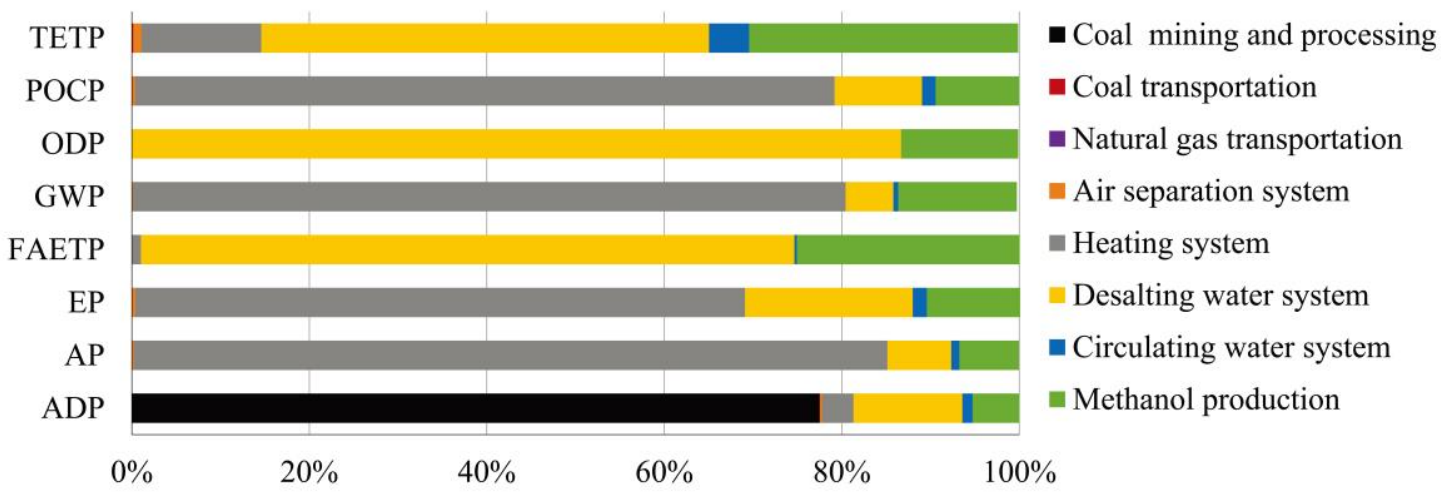

Fig. 6. Contributions of the coal gasification technology sub-processes to the environmental impacts.

The contributions of the sub-processes to the impacts of the CCT are shown in Fig. 7. The coking process contributed $>20 \%$ of the impacts except for ADP. Methanol production contributed $13.00 \%-54.98 \%$ of the impact categories, contributing most to FAETP and least to ADP. Heating contributed considerably more to AP, EP, GWP, and POCP than to the other categories.

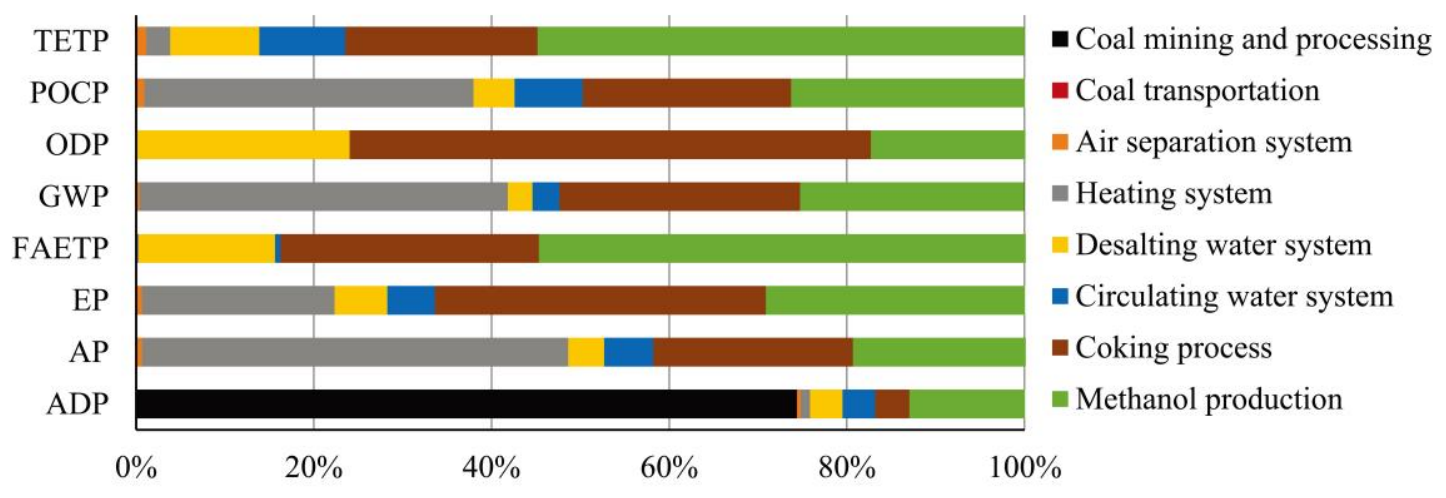

Fig. 7. Contributions of the coal coking technology sub-processes to the environmental impacts.

The first iteration indicated that land transformation and ozone layer depletion 373 (indicating ecosystem quality and human health, respectively) made much smaller 374 contributions than the other categories, so they were excluded from further analysis.

375 The results of the impact assessment at the EP level are shown in Table 5.

$376 \quad$ Table 5

377 Environmental performance at the end-point level

\begin{tabular}{llllll}
\hline Category & Damage & Unit & CGT & CCT & CGT/CCT \\
\hline EQ & AC/NC & PDF $^{2} \mathrm{~m}^{2 * a}$ & $2.34 \mathrm{E}+02$ & $5.10 \mathrm{E}+01$ & 4.6 \\
& EC & PDF $^{2 *} \mathrm{~m}^{2} \mathrm{a}$ & $9.08 \mathrm{E}+01$ & $4.07 \mathrm{E}+01$ & 2.2 \\
\hline
\end{tabular}




\begin{tabular}{llllll}
\hline Category & Damage & Unit & CGT & CCT & CGT/CCT \\
\hline \multirow{3}{*}{$\mathrm{HH}$} & LU & PDF* $\mathrm{m}^{2 * \mathrm{a}}$ & $9.05 \mathrm{E}+00$ & $1.67 \mathrm{E}+00$ & 5.4 \\
& CE & DALY & $5.18 \mathrm{E}-03$ & $2.10 \mathrm{E}-03$ & 2.5 \\
& CC & DALY & $3.70 \mathrm{E}-03$ & $6.05 \mathrm{E}-04$ & 6.1 \\
& RA & DALY & $3.00 \mathrm{E}-06$ & $3.80 \mathrm{E}-07$ & 7.9 \\
& IR & DALY & $7.06 \mathrm{E}-03$ & $1.59 \mathrm{E}-03$ & 4.4 \\
& OR & DALY & $7.09 \mathrm{E}-07$ & $2.67 \mathrm{E}-07$ & 2.7 \\
\hline EQ & & PDF* ${ }^{2 * a}$ & $3.34 \mathrm{E}+02$ & $9.33 \mathrm{E}+01$ & 3.6 \\
HH & & DALY & $1.59 \mathrm{E}-02$ & $4.29 \mathrm{E}-03$ & 3.7 \\
\hline
\end{tabular}

As shown in Fig. 8, somewhat more environmental damage was found for the CGT than for the CCT, so the CCT will be more acceptable. The results matched the results at the MP level. In general, the values for the damage caused by the CGT to ecosystem quality and human health were $334 \times$ potentially disappeared fraction $\times \mathrm{m}^{2} \times$ a and 0.016 disability adjusted life years, respectively, which were about 3.6 and 3.7 times higher, respectively, than the values for the CCT. Radiation and climate change (both affecting human health) were affected very differently by the different methods, and land utilization, acidification/eutrophication, and inhalable inorganic matter were affected somewhat differently by the different methods. Eco-toxicity, carcinogenic effects, and inhalable organic matter were affected similarly by the different methods.

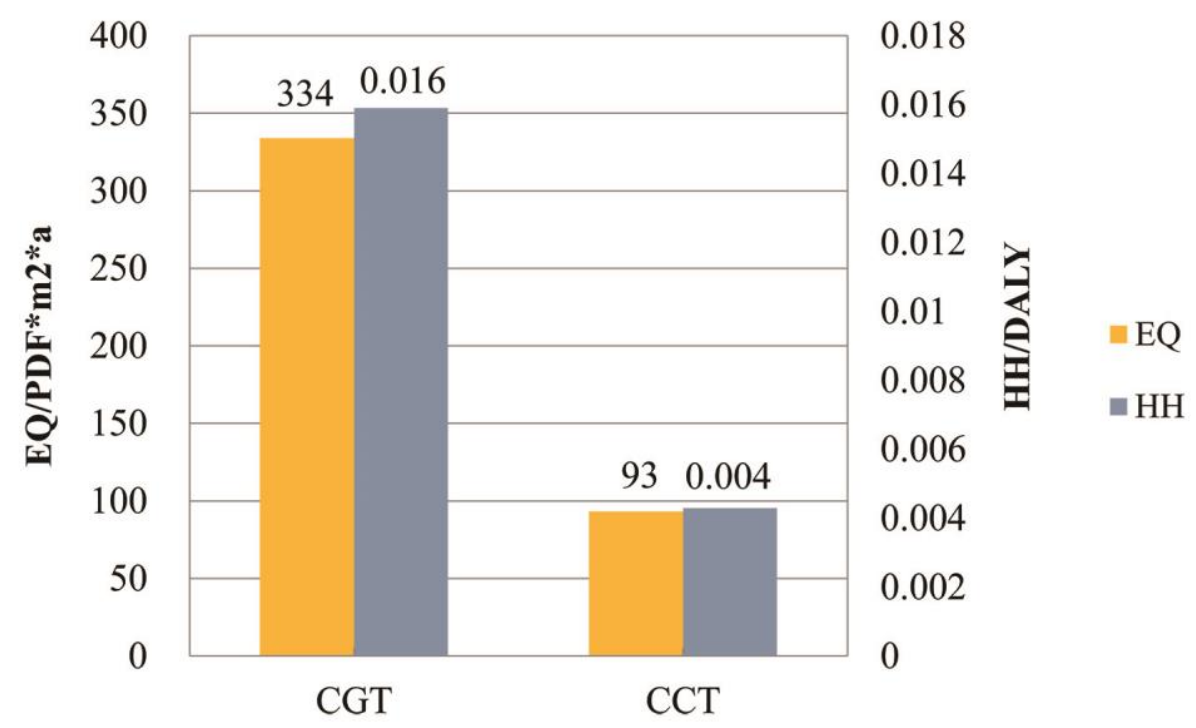

Fig. 8. Environment performances for the coal gasification technology (CGT) and coal coking technology (CCT).

In terms of ecosystem quality (see Fig. 9), acidification/eutrophication and ecotoxicity were the main categories affected by the CGT (accounting for $70.06 \%$ and $27.19 \%$ of the impact categories, respectively). The construction of factory buildings and infrastructure was not included, and the land-use value was relatively small $(2.71 \%)$. 


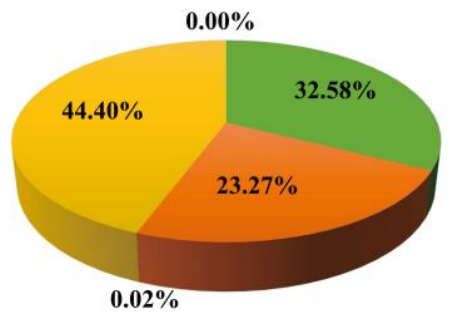

(a) CGT method was relatively small.

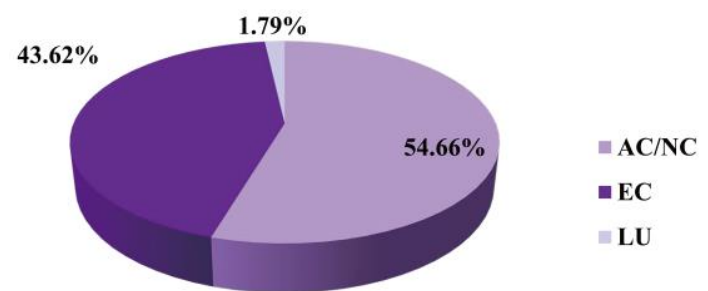

(b) CCT method

Fig. 9. Comparative damage to ecosystem quality for the (a) coal gasification technology (CGT) and (b) coal coking technology (CCT).

In terms of human health (see Fig. 10), different impact categories were affected to different degrees, but carcinogenic effects, climate change, and inhalable inorganic matter were the main factors affected by both methods. For example, the CGT affected radiation and inhalable organic matter very little, but inhalable inorganic matter was affected most (44.40\% of the total impact), followed by carcinogenic effects and inhalable inorganic matter. The CCT affected carcinogenic effects the most (48.95\% of the total impact), followed by inhalable inorganic matter. The impact on climate change

Fig. 10. Comparative results for damage to human health from the (a) coal gasification technology (CGT) and (b) coal coking technology (CCT). 
417 different degrees. The two methods caused damage to different categories affecting

418 human health. Therefore, different priorities will need to be used when designing

419 mitigation measures for the two methods.

420 3.3.2. Comparative process impact analysis

In the same way as for the MP level, the impacts of the two methods were calculated for five processes (raw material preparation, transportation, auxiliary engineering processes, public engineering processes, and methanol production). As shown in Fig. 11, the CGT had about 73\% stronger impacts than the CCT on all the raw material preparation categories. This was because more energy and resources are consumed during the CGT than during the CCT. The environmental impacts (except for climate change and inhalable organic matter) were lower for the CGT methanol production process than for the CCT methanol production process. The auxiliary engineering process, transportation processes, and public engineering processes all had stronger impacts for the CGT than for the CCT. The main reason for this may have been that more environmental damage is caused by the CGT than the CCT. The same conclusions were drawn from the MP level results. The results for these supporting processes were determined directly from the demand and cyclic use rates for raw materials and accessories for the entire methanol production process. 
AC/NC

EC

LU

CE

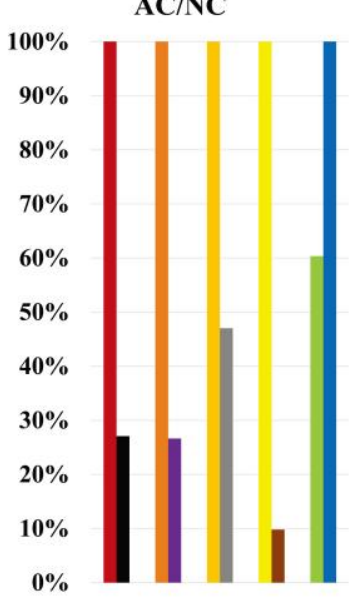

\begin{tabular}{l}
$100 \%$ \\
$90 \%$ \\
$80 \%$ \\
$70 \%$ \\
$60 \%$ \\
\hline $50 \%$ \\
$40 \%$ \\
$30 \%$ \\
\hline $20 \%$ \\
\hline $10 \%$ \\
\hline $0 \%$
\end{tabular}

$100 \%$

r

$100 \%$

$\mathrm{CC}$

RA
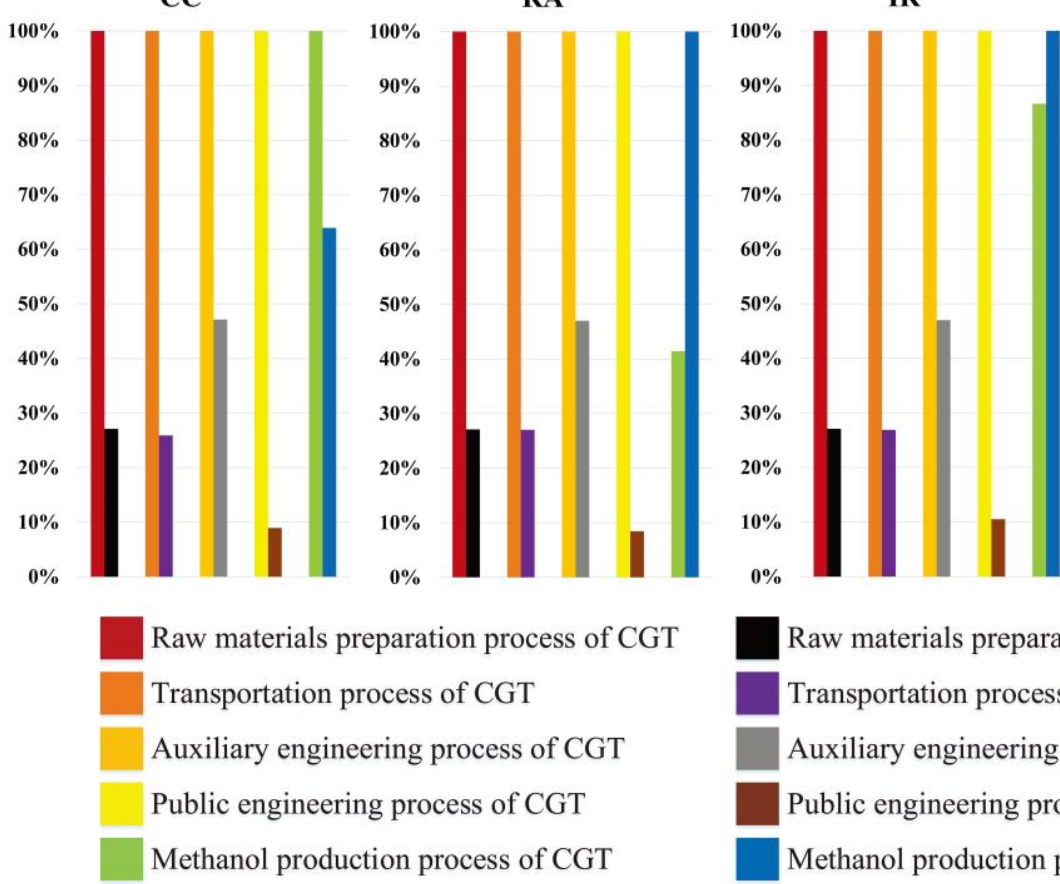

OR

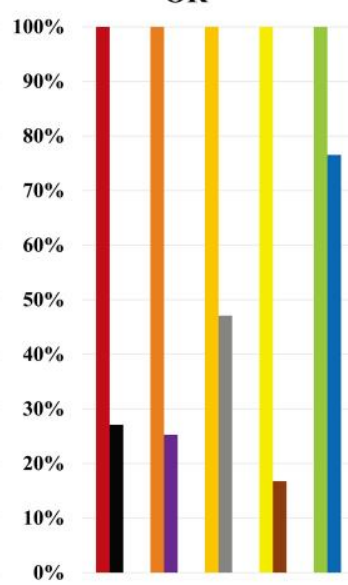

Raw materials preparation process of CCT

Transportation process of CCT

Auxiliary engineering process of CCT

Public engineering process of $\mathrm{CCT}$

Methanol production process of CCT

Fig. 11. Environmental impact assessment results for the coal gasification technology (CGT) and coal coking technology (CCT) processes at the end-point level.

\subsubsection{Comparative sub-process impact analysis}

The contributions of the CGT sub-processes to the environmental impacts at the EP level are shown in Fig. 12. The environmental damage caused by methanol production, heating, and desalination were all comparatively serious. Ecosystem quality damage was caused mainly by heating, which accounted for $62.31 \%$ of the total impact. Desalination and methanol production were the next biggest contributors, contributing $19.90 \%$ and $14.41 \%$, respectively, of the total impact. Human health damage was caused mainly by heating, followed by desalination and methanol production. The other sub-processes made smaller contributions to these two impact categories. Natural gas transportation contributed $<0.01 \%$ of almost all the impact categories, so could be considered to be negligible. 


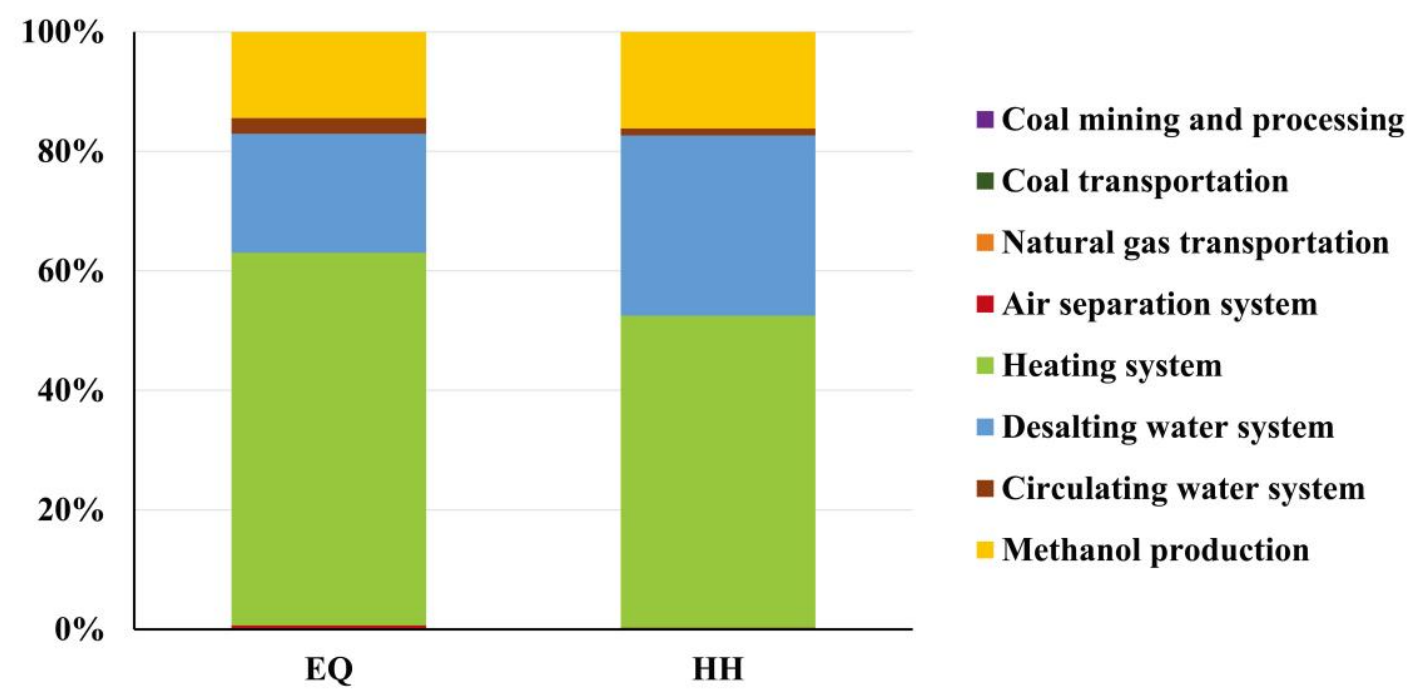

Fig. 12. Contributions of the coal gasification technology sub-processes to environmental damage.

The contributions of the CCT sub-processes to the environmental impact categories at the EP level are shown in Fig. 13. Coking, methanol production, and heating were the main contributors to ecosystem quality and human health damage. Methanol production had the strongest impacts, followed by coking and heating. Methanol production contributed $62.31 \%$ and $52.38 \%$ of the total ecosystem quality and human health impacts, respectively, because of direct and indirect emissions during production. About $28 \%$ of the CCT contribution to the ecosystem quality and human health impacts came from coking and heating, but the effects were stronger on ecosystem quality than human health. The impacts of desalination and circulating water were relatively small but could not be neglected. Desalination affected human health more, and circulating water affected ecosystem quality more.

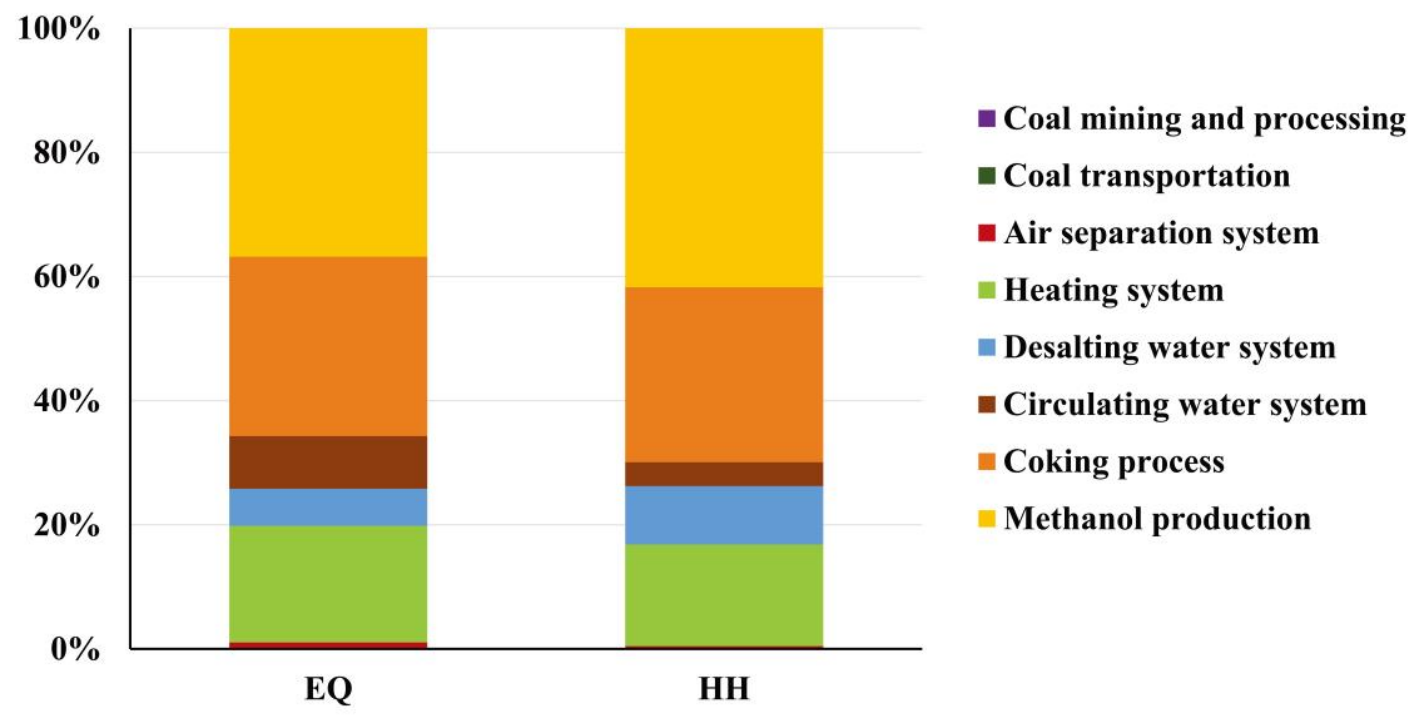


Fig. 13. Contributions of the coal coking technology sub-processes to environmental damage.

\subsection{Uncertainty analysis}

The accuracy and comprehensiveness of the data used are the important foundations for a LCA model and for LCA research, and therefore important prerequisites for reliable conclusions to be drawn. Sulfur emission data for different sources have been used in previous comparative studies, and the results indicated that the survey data were accurate. We preferred to use data from spot investigations, but the businesses required some data to be kept secret. The data therefore contained some uncertainty, and this will have caused uncertainty in the results. We performed a qualitative uncertainty analysis of the system boundary, distribution coefficients, and unit dataset, and our conclusions allowed the direction further research should take to be identified.

\subsubsection{System boundary}

The system boundary definition is the basis of a LCA, and different system boundaries will strongly affect the results obtained. Our data did not include infrastructure construction, which may have led to the environmental impacts, especially on terrestrial habitats, the soil, and land use, to be underestimated. The construction process should be within the system boundaries of future studies if appropriate data are available.

\subsubsection{Distribution coefficients/ratios}

An important characteristic of the coal-based chemical industry is that not only products but various by-products are produced. The by-products should share the environmental burden or damage caused by the whole process. Different methods of distributing the environmental burden affect the assessment results. The environmental burden or damage is usually distributed according to mass, volume, or energy. The diverse products and by-products led us to distribute the environmental burden or damage on the basis of energy. The methanol distribution coefficients for the CGT and CCT were $80.92 \%$ and $13.80 \%$, respectively. Under this distribution principle, the overall assessment result was better for the CCT than for the CGT at both the MP and EP levels. This means that, from the environmental perspective, coal-based methanol is better produced from coke oven gas than using a modern coal gasification system.

We determined the effect of the distribution coefficients used on the results treating other products or by-products as incidental emissions of the major product (methanol), without adding additional value. We assumed that both methods took no account of the environmental burden or damage distribution for other products and byproducts, and compared these worst-case values. That is, the methanol distribution coefficients for both methods were both $100 \%$. The CCT distribution only took the coking process into consideration, so the CCT values were smaller than the 
characteristic values shown in Table 6. At the MP level, the CGT offered advantages for all the impact categories except AP and GWP. The CGT offered advantages for all the impact categories except for climate change and radiation at the EP level. Overall, however, the impacts of both methods were in the same order of magnitude, so the environmental burdens and damages for both methods were the same in the worse-case scenario but the CGT was better than the CCT for some impact categories. Therefore, the comprehensive utilization for by-products was an important factor for coal-based methanol production.

\section{Table 6}

Characteristic values for the worst-case values for the coal gasification technology (CGT) and coal coking technology (CCT) at the mid-point (MP) and end-point (EP) levels

\begin{tabular}{llllll}
\hline Category & $\begin{array}{l}\text { MP level } \\
\text { CGT }\end{array}$ & CCT & Category & $\begin{array}{l}\text { EP level } \\
\text { CGT }\end{array}$ & CCT \\
\hline ADP & $1.07 \mathrm{E}+05$ & $1.78 \mathrm{E}+05$ & AC/NC & $2.89 \mathrm{E}+02$ & $3.70 \mathrm{E}+02$ \\
AP & $9.11 \mathrm{E}+01$ & $7.91 \mathrm{E}+01$ & EC & $1.12 \mathrm{E}+02$ & $2.95 \mathrm{E}+02$ \\
EP & $6.15 \mathrm{E}+00$ & $9.64 \mathrm{E}+00$ & LU & $1.12 \mathrm{E}+01$ & $1.21 \mathrm{E}+01$ \\
FAETP & $4.51 \mathrm{E}+02$ & $1.07 \mathrm{E}+03$ & CE & $6.40 \mathrm{E}-03$ & $1.52 \mathrm{E}-02$ \\
GWP & $2.19 \mathrm{E}+04$ & $2.09 \mathrm{E}+04$ & CC & $4.57 \mathrm{E}-03$ & $4.38 \mathrm{E}-03$ \\
ODP & $1.69 \mathrm{E}-05$ & $3.01 \mathrm{E}-05$ & RA & $3.71 \mathrm{E}-06$ & $2.75 \mathrm{E}-06$ \\
POCP & $4.36 \mathrm{E}+00$ & $4.59 \mathrm{E}+00$ & IR & $8.72 \mathrm{E}-03$ & $1.15 \mathrm{E}-02$ \\
TETP & $2.34 \mathrm{E}+01$ & $5.78 \mathrm{E}+01$ & OR & $8.76 \mathrm{E}-07$ & $1.93 \mathrm{E}-06$ \\
\hline
\end{tabular}

\subsubsection{Unit dataset}

The data were mostly obtained from the investigations at the plants, but some processes were substituted with other similar processes included in the GaBi6 or Ecoinvent databases. For example, for desalination, high-salinity water was replaced with production wastewater because high-salinity water was not present in the databases. However, it is more complex and more chemicals are required to dispose of production wastewater than high-salinity water, causing the environmental impacts of desalination to be overestimated. Since the average desalting water consumption for CGT and CCT were $5.12 \mathrm{t}$ per ton and $0.41 \mathrm{t}$ per ton, respectively, the environmental impacts of desalination of CGT were much higher that of CCT. The replacement of dataset had a limited impact on the analysis results. We will reexamine the dataset to improve the reliability of the results.

\section{Conclusions}

The Chinese coal-based chemical industry is growing rapidly, and methanol production in China will soon account for more than $50 \%$ of global production. Coalbased methanol production is an important part of the Chinese coal-based chemical industry, but has important environmental impacts. The LCA method was used to evaluate the environmental impacts of producing $1 \mathrm{t}$ of coal-based methanol using the 
CGT and CCT based on the companies that represent the current domain coal-based methanol technologies in China. The environmental performances of the two different methods were examined at the MP and EP levels. We improved the LCI database for intermediate industrial products for further research. The comparative LCA results have the implications for policy described below, which may prompt companies to upgrade their technologies and industrial structure.

(1) The CGT is generally seen as being more advanced than the CCT in terms of production. Surprisingly, however, the environmental burden is more severe for the CGT than the CCT. Environmental damage analysis based on the LCI indicated the CCT has a relatively small burden on coal resources and water resources, and produces smaller amounts of typical air pollutants than the CGT. From the coal-based methanol life-cycle perspective, CCT is a more environment-friendly technology for two main reasons. The by-products of CCT share most of environmental impacts while the products of CGT bear most of those impacts. Moreover, the environmental impacts of heating system and desalination of CGT are much stronger than that of CCT.

(2) The environmental impacts of auxiliary engineering processes and public engineering processes should not be ignored. Public engineering processes are the dominant contributors to the marked differences between the environmental impacts of the two methods. Heating and desalination contribute more than the production process to the total impact. The CCT methanol production process has a stronger impact than the CGT methanol production process, but the environmental impacts of other processes involved in the CGT are more important than the CGT methanol production process. Essentially, the CGT shifts the environmental impacts from the methanol production process to other processes, so the CGT cannot be seen as a cleaner method than the CCT from the viewpoint of environmental impacts.

(3) The different sub-processes made very different contributions to the different environmental impact categories. We found that there is great potential for decreasing the environmental impacts of the CGT by improving the heating and desalination systems. The CCT could be improved by decreasing the impacts of the coking and methanol production processes.

\section{Acknowledgements}

This research was supported by the Tianjin Natural Science Foundation (grant number 15JCQNJC09200), Humanity and Social Science Youth Foundation of the Ministry of Education of China (grant number 17YJCZH002), and the Institute of Ecological Civilization, Nankai University. We thank Gareth Thomas, $\mathrm{PhD}$, from Liwen Bianji, Edanz Group China (www.liwenbianji.cn/ac), for editing the English text of a draft of this manuscript. 


\section{References}

Bhopal, R.S., Phillimore, P., Moffatt, S., Foy, C., 1994. Is living near a coking works harmful to health? A study on industry air pollution. J. Epidemiol. Community Health 48, 237-247.

Borjesson P, Tufvesson L.M., 2011. Agricultural crop-based biofuels - resource efficiency and environmental performance including direct land use changes. J. Clean. Prod. 19, 108-120.

Brynolf S., Fridell E., Andersson K., 2014. Environmental assessment of marine fuels: liquefied natural gas, liquefied biogas, methanol and bio-methanol. J. Clean. Prod. 74, 86-95.

Cao K., Feng X., 2006. Energy analysis and comparison of methanol synthesis processes using different feedstocks. Chemical Industry and Engineering Progress. Beijing, China.

Centre for Environmental Studies, 2001. CML 2 Baseline Method 2000. Centre for Environmental Studies, University of Leiden, Leiden, the Netherlands.

Chen D.J., Zhu B., Zhang B., Ma Y.Y., Hu S.Y., Jin Y., 2008. Analysis on Perspective and Problems of Methanol-DME Economy in China. Chemical Industry. Beijing, China.

Deniz C., Zincir B., 2016. Environmental and economical assessment of alternative marine fuels. J. Clean. Prod. 113, 438-449.

Dreyer L.C., Niemann A.L., Hauschild M.Z., 2003. Comparison of three different LCIA methods: EDIP97, CMML2001 and Eco-indicator 99. Does it matter which on you choose. International journal of Life Cycle Assessment 8,191-200.

Du J.Y., J.Y., Yuan Y.N., Zhang D.P., 2012. Life Cycle impact assessment of coalbased methanol and natural gas-based methanol fuel. Renewable Energy Resource, Yingkou, China.

Futures Daily, 2017. Overview of global methanol market capacity. Available from: http://www.qhrb.com.cn/2017/0329/210313.shtml.

General Administration of Quality Supervision, Inspection and Quarantine of the P.R. China, Methanol for Industry Use (GB 338-2004).

General Administration of Quality Supervision, Inspection and Quarantine of the P.R. China, General Principles for Calculation of the Comprehensive Energy Consumption (GB/T 2589-2008).

Goedkoop, M., Spriensma, R., 1999. The Eco-indicator 99 - A damage oriented method for life cycle impact assessment. PRe Consultants: Amersfoort, the Netherlands.

Goran F., Michael Z.H., Tomas E., Jeroen G., Reinout H., Stefanie H., Annette K., David P., Sangwon S., 2009. Recent developments in life cycle assessment. Journal of Environmental Management 91, 1-21.

Grote K.H., Antonsson E.K., 2009. Springer Handbook of Mechanical Engineering. 
Springer Berlin Heidelberg, Berlin, Germany.

Guinee J.B., Gorrée M., Heijungs R., Huppes G., Kleijn R., 2001. Handbook on Life cycle assessment: Operational Guide to the ISO Standards. Dordrecht, Netherlands.

Hofstetter P., 2000. Perspectives in life cycle impact assessment; a structured approach to combine models of the technosphere, ecosphere, and valuesphere. International Journal of Life Cycle Assessment 5(1): 58-58.

Huisman J., 2003. The QWERTY (EE) Concept - quantifying Recyclability and Ecoefficiency for End-of-life Treatment of Consumer Electronic Products. Doctor thesis. Delft University of Technology.

International Organization for Standardization, 2006. 14040 Series: Environmental Management - Life Cycle Assessment - Principles and Framework (Geneva, Switzerland).

Jackson R.G., 1989. Polygeneration system for power and methanol based on coal gasification. Coal Conversion (3): 60-64.

Li M, 2011. Development of basis methanol in China. Clean Coal Technology, Beijing, China.

Li Z., Gao D., Chang L., Liu P., Pistikopoulos E.N., 2010. Coal-derived methanol for hydrogen vehicles in China: Energy, environment, and economic analysis for distributed reforming. Chemical Engineering Research \& Design 88, 73-80.

Liu H.L., Cao F.Z., 2008. "Springing phenomenon" of coal chemical industry and the constraint of environment and resources. Journal of China University of Geosciences (Social Sciences Edition), Wuhan. China.

Liu W.G., Han J.Y., Xiong Z.J., Liu X.R., 2015. The current development situation and trends of the new coal chemical industry. China Coal, Beijing, China.

Liu X., Yuan Z., 2016. Life Cycle Environmental Performance of By-product Coke Production in China. J. Clean. Prod. 112, 1292-1301.

Lu D.X., 2005. Cleaner production about carbinol made of coal, China resources comprehensive utilization, Xuzhou, China.

Luan, 2004. Environmental attributes assessment of product green design and its application based on the Eco-indicator99. Light Industry Machinery, Hangzhou, China.

National Development and Reform Commission, 2017. Layout Scheme for Innovation Development of Modern Coal Chemical Industry.

Parodi, S., Stagnaro, E., Casella, C., Puppo, A., Daminelli, E., Fontana, V., Valerio, F., Vercelli, M., 2005. Lung cancer in an urban area in Northern Italy near a coke oven plant. Lung cancer 47, 155-164.

PE International, 2012. GaBi 6 Software and Databases (Leinfelden-Echterdingen, Germany). 
SCI99.COM, Capacity and output database of methanol in China, 2017. China, Available from: http://ie.sci99.com/Product/40/2017.

Shi M.X., Wang T.L., Shi F., 2010. Production technology progress and market prediction of methanol. Science \& Technology in Chemical Industry, Jilin, China.

Soam, S., Kumar, R., Gupta, R.P., Sharma, P.K., Tuli, D.K., Das, B., 2015. Life cycle assessment of fuel ethanol from sugarcane molasses in northern and western India and its impact on Indian biofuel programme. Energy 83, 307-315.

The State Council of China, 2008. Emission Factor Manual for the $1^{\text {st }}$ National Census of Industrial Pollution Sources. Beijing, China.

Wei Y., 2014. Analysis and Trend Prospects of Methanol Market in China. Chemical Fertilizer Industry, Shanghai, China.

Wei Y.C., Deng S.P., Jiang Y.F., 2007. Analysis of life cycle greenhouse gases emission of coal-based methanol and coal-based F-T diesel. Coal Conversion, Taiyuan, China.

Weidema B., Hischier, R., 2006. Ecoinvent Data v2. 2 (St. Gallen, Switzerland).

Wu B., Wang L.J, Shen X.W., Yan R.B., Dong P., 2016. Comparison of lean burn characteristics of an SI engine fueled with methanol and gasoline under condition. Applied Thermal Engineering, 95, 264-270.

Xia C., Xie X.M., Zhang T.T., Huang Z., 2015. Life cycle analysis of the COG to methanol fuel. Coal Chemical Industry, Taiyuan, China.

Xiao X.J., 2015. Analysis of Domestic and International Methanol Industry and Market. Coal Chemical Industry, Taiyuan, China.

Xiao X.J., 2010. Analysis and prospect of the development of methanol industry in China since the financial crisis. Energy of China, Beijing, China.

Xie K.C., Li W.Y., Zhao W., 2010. Coal chemical industry and its sustainable development in China. Energy 35, 4349-4355.

Xu Z.G., Chen Y.F., 2007. Present status of coal chemical technology in China and development countermeasures. Coal Science and Technology, Beijing, China.

Yang C.J., Jackson R.B., 2012. China's growing methanol economy and its implications for energy and the environment. Energy Policy. 41, 878-884.

Yang S.B., Wang J.R., Wang Z.H., 2001. Status and development of coal basis methanol in China. Clean Coal Technology, Beijing, China.

Zhang H., Wang S.J., Li Z., Ni W.D., 2005. Well-to-tank Life Cycle Assessment for Coal Derived Methanol Fuel. J Tsinghua Univ (Sci \& Tech). Beijing, China.

Zhang X., 2012. Research on the path selection of alternative automobile fuels based on the LCA theory. Tianjin University, China.

Zhang X.M., 2017. The industrialization feasibility and prospect of China methanolfueled automobile under the restriction of energy and environment. China University of Geosciences (Beijing), China. 
684 Zhu L.N., 2006. Comprehensive assessment of alternative vehicle fuel scenarios based 685 on life cycle. Chongqing University, China. 